\title{
The Effect of Students' Digital Literacy Skill to the Quality of Accounting Learning in Self-Directed Learning as Moderating Variables
}

\author{
Dwi Puji Astuti ${ }^{1}$, Kardiyem $^{2}$, Wulan Suci Rachmadani ${ }^{3}$, Saringatun Mudrikah ${ }^{4}$ \\ \{dpastuti@mail.unnes.ac.id ${ }^{1}$ \} \\ Universitas Negeri Semarang, Indonesia ${ }^{1,2,3,4}$
}

\begin{abstract}
This study aims to test digital literacy's impact on the quality of accounting learning with self-directed learning as a moderation variable. The learning process is often faced with problems relating to the quality of learning. The learning process's objectives have many essential aspects of being aware of, including digital literacy and self-directed learning capabilities. Digital literacy in education, especially in higher education, has the consequences of learning design by utilizing digital media to improve learning quality. This research uses a quantitative approach type. This research population is students of the Department of Accounting Education, Universitas Negeri Semarang, the year 2017, which has 75 students. The sampling technique is a saturated sampling. Data collection and retrieval methods using questionnaire poll. Data analysis techniques using IBM SPSS Statistic 26.0 regression moderation analysis, the year 2020. The results showed that digital literacy has no a significant and positive impact on the quality of learning, and selfdirected learning can moderate the positive influence of digital literacy on the quality of learning.
\end{abstract}

Keywords: Digital Literacy, Self-Directed Learning, Quality Learning.

\section{Introduction}

A learning process is often faced with problems relating to the quality of learning. The quality of learning depends on the educators ' ability to develop effective and efficient learning processes. In achieving these objectives, in learning activities, there are two essential aspects to be aware of. First, the learning aspect is several intellectual, emotional, and physical experiences in the students. Second, the learning aspect is the behavior change in the learners. Implementing operational learning activities is to teach students to process and acquire knowledge, skills, and attitudes.

The quality of learning is closely related to the use of optimal teaching methods to achieve learning objectives. To achieve a good quality of learning, lecture materials must be arranged with the right strategy. Furthermore, the material is delivered to the students with the appropriate delivery strategy. Learning should be able to make the material as taught attractive to affect students' process and learning outcomes. Learning quality is also influenced by learning orientation factors, internationalization, and also self-reliance on learners.

The mastery of information and communication technology by educators and learners is essential. It needs to apply in the educational process. 21 st-century education demands 
educational institutions to be responsive to developments and changing times by mastering information technology or digital literacy. The development of information technology became part of the emergence of the digital revolution ERA in Indonesia. Its rapid development can significantly influence and dominate the entire community life sector, including the world of education. Based on The World Summit on The Information Society (WSIS) Declaration stating that "where everyone can create, access, utilize and share Information and knowledge, enabling individuals, communities, and peoples to achieve their full potential in promoting their sustainable development and improving their quality of life...[1]. Anyone can create, access, use, and share or share information, and knowledge, with the consequences that everyone must be able to face and adequately master the information [2]. However, the ease in sharing and accessing digital information over the Internet, resulting in many students who use the information that can not account for widely circulating through various digital media publications such as blogs or WordPress that does not include the clarity of information sources as a reference in completing his academic duties.

In order to cope with the condition, a particular skill is known as the term literation pattern. Indonesia has proclaimed the National Literacy Movement to accelerate Indonesia's still-low level of literacy culture. A survey conducted by Central Connecticut State University (2016) showed that Indonesia was 60 from 61 states of PISA score. The country of Indonesia was in order to 64 from 72 country scores, still showing fewer categories. In 2003, the United Nations (PBB) held a world meeting in Prague to discuss literacy intelligence, bearing in mind the importance of literacy for world citizens facing the swift flow of information technology.

Further [3] stated that the pattern of literacy is a form or structure that occurs in a continuous state carried out by a group of people in conducting a series of learning ranging from the stage of receiving and reading to the stage of creating. One kind of literacy related to the unique ability to use various digital format information is digital literacy. According to Sholihah, Digital literacy attempts to find, use, or disseminate information effectively [4]. Academic demands on each level of education in Indonesia vary [5].

Digital literacy in education, especially in higher education, has the consequences of learning design by utilizing digital media to improve student knowledge. Digital Media can present exciting and interactive contextual, audio, and visual learning materials [6]. As part of higher education institutions, universities must adapt themselves to conduct a digital-based learning process. Digital literacy in universities can be done with the communication and collaboration step of active participation in digital networks for learning and research. As part of higher education institutions, universities must adapt themselves to conduct a digital-based learning process. Today's information and Internet technologies' progress resulted in very abundant digital information resources [7]. Such circumstances will support the program's internationalization of universities, especially in improving the quality of education.

Accounting education students, as prospective accounting educators, are responsible for practicing the knowledge gained in education. The always dynamic educational world demands students as a prospective education to always update against science and technology accounting. Based on the researcher's observation of the Department of Accounting Education Faculty of Economics Universitas Negeri Semarang phenomenon, students who succeed in the task process do not rely entirely on others. They have the initiative to keep searching, finding, and choosing what they need. Besides, they are also skilled in arranging the time to construct assignments and can arrange schedules to discuss the ideas they have made. If reviewed theoretically, these students' circumstances, such as not relying on others, have their initiatives in learning, and set the time, is an overview of self-learning skills (Self-Directed Learning). 
The term Self-Directed Learning (SDL) is found in the psychology Literature of adult education [8]. According to Gibbons [9], SDL is a skill where one can determine for itself and choose the objective to achieve, plan the strategy to be done, try to solve the problem, manage itself, and evaluate the thinking and performance that do. These skills will enhance personal knowledge, expertise, and achievements [9]. The research Hyland and Kranzow [10] revealed that SDL positively influences undergraduate and graduate-level students' academic performance. Self-Directed Learning (SDL) is also an essential student to complete the task [11].

One student revealed that the task process feels better when dealing directly with the digital devices they have. This is in line with PEnelitian done [12]. It also shows the results that digital literacy has a positive influence on the quality of learning. Digital Literation can contribute to more efficient task completion through software and computer programs, such as word processors or spreadsheets [13].

Grant [14] exposes research results on the implementation of digital literacy at some schools in the UK that emphasize some key points, such as giving room to students to select subject matter, triggering learners' independence to learn, and improving communication skills among students' use digital technology. It shows in a digital age like this, SDL cannot detach from digital literacy. That means the skills of SDL in the learning process can increase through excellent digital literacy skills.

The quality of learning is a strategic destination for every higher education institution. Many higher education institutions apply specific learning and have designed mechanisms and instruments to improve education quality. The use of technology and individual digital devices gave the space to develop SDL skills through various activities and existing resources such as participation in online learning groups, reflective writing activities, and online dialogue [15]. The results also showed that there was a positive correlation between digital literacy and quality Learning for learners studying in an online-based environment online [10].

The quality of learning is a strategic destination for every higher education institution. Many higher education institutions apply specific learning and have designed mechanisms and instruments to improve education quality. The use of technology and individual digital devices gave the space to develop SDL skills through various activities and existing resources such as participation in online learning groups, reflective writing activities, and online dialogue [15]. The results also showed that there was a positive correlation between digital literacy and quality Learning for learners studying in an online-based environment online [10].

The purpose of this research is two. The first goal is to review, analyze, and describe the positive and significant influences of digital literacy on accounting learning quality. The second goal is self-directed learning influences in moderate the positive influence of digital literacy on quality of learning.

\section{Research Methods}

This research is a type of quantitative study aimed at testing a predetermined hypothesis using statistical data analysis. Quantitative research was realized in numeric form and analyzed statistically to know the role of Self-Directed Learning (SDL) as moderating digital literacy guru to the quality of learning in accounting education students of Universitas Negeri Semarang, the year 2017. The design of the research used is hypothesis testing studies. The data used in this research is primary data with the data retrieval techniques using polls or 
questionnaires distributed to respondents based on predetermined samples. Hypothesis testing in data analysis using IBM SPSS Statistic 26.0 analysis tools, the year 2020.

This research population is students of the Department of Accounting Education, Universitas Negeri Semarang, the year 2017, which has 75 students. The sampling technique is saturated sampling with the number of respondents equal to the population.

The binding variables used in the study are the quality of accounting learning with indicators that contribute to the quality of learning include students' characteristics, learning environment, learning facilities and infrastructure, approaches in learning, and learning outcomes [16]. The independent variables used are Digital literacy. The moderating variables used are Self-Directed Learning (SDL). Digital Literacy variables using indicators consisting of information literacy, Digital Scholarship, learning skills, ICT literacy, privacy management, Communication and collaboration, and media literacy [17]. Self-Directed Learning (SDL) variables use an indicator that is self-controlling the number of learning experiences that occur, transforming themselves into better performance, skill development, self-management, motivation, and self-assessment [8].

\section{Results and Discussion}

Statistic descriptive analysis of the study was obtained from the calculation of the interval scale. So we get the title of the variable quality of learning, digital literacy, Self-Directed Learning (SDL). Table 1 are the detailed results of statistic variables.

Table 1. Descriptive statistics variable results

\begin{tabular}{lccccc}
\hline \multicolumn{7}{c}{ Descriptive Statistics } \\
\hline KPA & N & Minimum & Maximum & Mean & Std. Deviation \\
\hline LD & 75 & 28 & 59 & 45.75 & 5.643 \\
\hline SDL & 75 & 47 & 59 & 54.87 & 2.195 \\
\hline Valid N (listwise) & 75 & 40 & 45 & 41.73 & 1.473 \\
\hline \multicolumn{7}{c}{ Source: Results of research data, 2020. }
\end{tabular}

Based on the results of descriptive statistical analysis, it can conclude that the dependent variable, i.e., accounting learning quality variable has the lowest value of 28 , the highest value of 59, and the average value of 45.75 . The variable, independent digital literacy, has the lowest value of 47 , the highest value of 5 , and the average value of 54.87 . The moderating variable is the variable Self-Directed Learning (SDL) has the lowest value of 40 , the highest value of 45 , and the average value is 41.73 .

Test the moderation effect done by testing the absolute difference values. Table 2 the results of the test analysis of absolute difference values.

Table 2. The test result of the absolute difference value

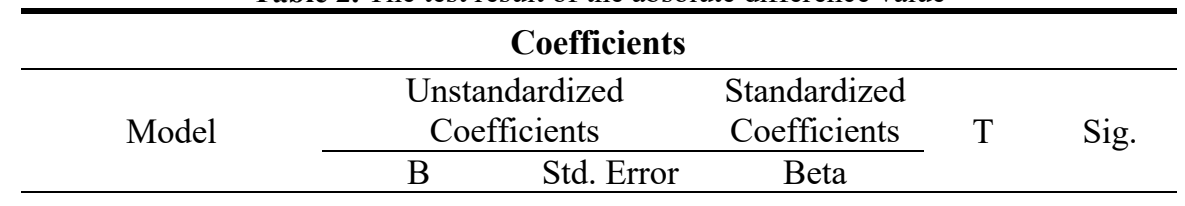




\begin{tabular}{llccccc}
\hline 1 & (Constant) & 1399.458 & 468.696 & & 2.986 & .004 \\
& LD & -24.921 & 8.462 & -9.696 & -2.945 & .004 \\
& SDL & -32.582 & 11.146 & -8.508 & -2.923 & .005 \\
& LDSDL & .600 & .201 & 12.884 & 2.981 & .004 \\
\hline \multicolumn{7}{l}{ a. Dependent Variable: KualitasPembel }
\end{tabular}

Source: Results of research data, 2020.

Based on the test result, the absolute difference in table 2 above then can be obtained coefficient of the independent variable of digital literacy (LD) is, the variable coefficient of Self-Directed Learning (SDL) is-24.921, the coefficient of digital literacy interaction and SelfDirected Learning (SDL) is 0.600. Based on these results, multiple regression equations can be generated as figure 1 .

$$
\mathrm{KPA}=1399.458-24,921 \mathrm{LD}+0,600[\mathrm{LD}-\mathrm{Z}]+468,696 \dot{\mathrm{e}}
$$

Fig. 1. Multiple regression equations

A moderation regression model can be presented in the figure 2 .

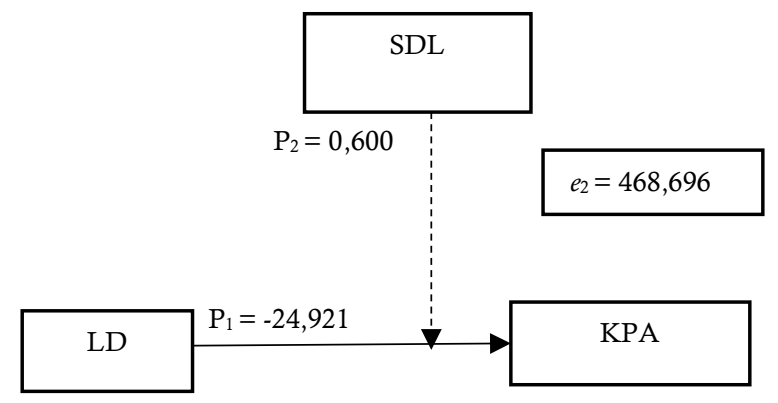

Fig. 2. The research model of moderation regression analysis

The above regression equation has a constant value of $1,399,458$, which means that when digital literacy and digital literacy interact with Self-Directed Learning (SDL) zero (0), the learning quality is worth $1,399,458$. The digital Literacy variable (LD) has a regression coefficient of-24.92 with a significance level of 0.004 , meaning that digital literacy variables negatively affect learning quality. The other term, the higher the digital literacy than the lower the quality of learning and vice versa. So it is understandable that the H1 stating the digital literacy variables are positively influential towards the quality of learning, rejected.

The regression coefficient of digital literacy interactions and Self-Directed Learning (SDL) is 0.600 . Suggests that Self-Directed Learning (SDL) as a moderating variable strengthens the positive influence of digital literacy on learning quality. This means that the higher the SelfDirected Learning (SDL) variable moderation role will be, the more positive the digital literacy variable is to the quality of learning, and vice versa. The variable regression coefficient of interaction between digital literacy and Self-Directed Learning (SDL) is 0.600 significant at 0.004 . This fact gives the meaning that with a $5 \%$ confidence rate of SelfDirected Learning (SDL) is significantly able to moderate the influence of digital literacy on 
the quality of learning. Based on these results, the $\mathrm{H} 2$ that states that Self-Directed Learning (SDL) strengthens the positive influence of digital literacy on learning quality is acceptable.

So that the test result of the absolute difference in table 2 can be created a model in this study as Table 3 .

Table 3. Result coefficient of determinations

\begin{tabular}{lllll}
\hline \multicolumn{1}{l}{ Model Summary } \\
\hline Model & $\mathrm{R}$ & R Square & $\begin{array}{l}\text { Adjusted } \\
\text { Square }\end{array}$ & $\begin{array}{l}\text { R } \\
\text { Std. The error } \\
\text { of the Estimate }\end{array}$ \\
\hline 1 & $.380^{\text {a }}$ & .144 & .108 & 5.32887 \\
\hline a. Predictors: (Constant), LDSDL, SDL, LD \\
\hline \multicolumn{5}{c}{ Source: Results of research data, 2020. }
\end{tabular}

According to table 3 , the magnitude adjusted $\mathrm{R}^{2}$ is 10.8 . Hal shows the variable quality learning can be described by the variable variances independent, the digit liberational. The remaining 80.2 is explained by other factors outside the model.

\subsection{Influence of Digital Literacy on Learning Quality}

The results showed, the first hypothesis testing (Ha1) mentioning that digital literacy has a positive and significant effect on the quality of learning, is rejected. The first hypothesis testing showed that the regression coefficient value amounted to -24.92 , with a significant rate of 0.004 . The value indicates the relationship between the digital literacy variable and the learning quality. It is harmful and significant because the significance value is less than that specified to 0.05 . However, the result's spirit is negative, unlike the hypotheses that state a positive effect. Based on the results, it can be concluded that Ha1, rejected.

The study results were not by the theory of involvement discovered by Astin (1984), namely that involvement refers to the investment of physical and psychological energy in the case of various objects. Whatever the object, student involvement occurs along the continuum. Involvement has quantitative and qualitative features. Personal learning and development related to the education program's attitude are directly proportional to the quality and quantity of student involvement in the program. This theory explains at the same time. The input factors have a relationship that will affect the environment and affect the outcome. Astin also explains that the relationship between the environment and the outcome cannot be separated from Kelly (1996) [18]. Input as the original quality of personal students brought like learning orientation. The environment is defined as the real experience of students during university education programs. Outcomes are defined as learning qualities. The student input does not affect the environment and outcome. In Indonesia, the term literation is still considered new because all circles have not entirely understood it. Many people also know about literacy but do not have the skills to develop well in all environments, like the World education environment.

Based on digital literacy analysis, variable frequency distribution has an average value of 54.87 and is in a very high category. Learning quality variables have an average value of 45.75. It means that students active in the Accounting Education Department of Universitas Negeri Semarang, the year 2017, to perceive that he has very high digital literacy. The high quality of learning is not influenced by very high digital literacy. Mobile phones and the like in the global era have become necessary for the community's citizens, including educators and students. However, it is only to fulfill the importance of communicating, preaching something, or looking for something. The phenomenon in the field that digital literacy and mobile phones 
can as learning media has not been developed proportionally, which may improve the quality of learning at the Universitas Negeri Semarang, especially the students of progressive accounting education in 2017. Digital literacy has been solely known in social media. It can convey information related to the citizens' things, but still not optimized to improve the quality of learning. Educators and students have not read much of the phenomenon well. Not able to utilize as a learning media and even learning resources, especially those associated with the implementation of curriculum and budding digital literacy. Virtual Media is now increasingly filled with news content lying, hate speech, even fraudulent practices. This is where each individual can put his consciousness into digital literate [19].

This study proved that the unity hypothesis was rejected and showed results by the Murray and Perez [20] that based on the assessment results of digital literacy carried out against final-level students at regional universities in the United States, stating that understanding of digital literacy cannot be likened to the exposure and interaction of students with digital technology in everyday life. Although students are primarily interacting with digital technology, they do not necessarily have excellent digital literacy skills in their living environment. Digital Literacy, in its implementation, has not optimally developed, and it is possible that it can contribute to improving the quality of learning in UNNES. So far, digital literacy is known as social media that can convey various information related to things needed by the community. Digital media should be empowered to develop learning synergistically to support improving the quality of learning. The phenomenon found that social Media is positioned to deliver messages/information from message senders to message recipients according to the needs [21]. This proves that high or low digital literacy does not affect high and low learning quality. To improve digital literacy on the quality of learning, there is a strategy to develop digital literacy enhancement for students who are in coherence, inclusive, and holistic student.

\subsection{The Influence of Self-Directed Learning (SDL) in Strengthening the Influence of Digital Literacy on the Quality of Learning}

The second hypothesis posed in this study is Self-Directed Learning (SDL), strengthening the positive influence of digital literacy on learning quality. This is based on a second hypothesis test indicating that the value of a regression coefficient of Self-Directed Learning (SDL) and digital literacy is with a significance value of 24.92 with a significant rate of 0.004 . These values demonstrate Self-Directed Learning (SDL), strengthening the positive influence of digital literacy to the quality of learning in strengthening the positive influence of digital literacy to the quality of learning with the provision of a significantly smaller value than the set value of 0.05 . Based on the results, it can be concluded that Ha2, accepted.

The results of this research are by the theory of involvement found by Astin (1984), namely that the isolation refers to the investment of physical and psychological energy in the case of various objects. Whatever the object, student involvement occurs along the continuum. Involvement has quantitative and qualitative features. Personal learning and development related to the education program's attitude are directly proportional to the quality and quantity of student involvement in the program. The effectiveness of each education policy relates to student involvement in student organizations attended by students. It demonstrates the relationship between the components in the theory of Astin I-E-O. The input and environment determine student outcomes. This theory explains at the same time that the input factors have a relationship that will affect the environment and affect the outcome. Astin also explains that the relationship between the environment and the outcomes cannot be separated from Kelly [18]. Input as the original quality of personal students brought in such learning orientation and 
Self-Directed Learning (SDL). The environment is defined as the real experience of students during university education programs. Outcomes are defined as learning qualities. It proves that Self Direct Learning can strengthen digital literacy's positive relationship to the quality of learning. The digital literacy of every student is very high but not completely understood. The existence of Self Direct Learning to control the many learning experiences that occur, transforming yourself into better performance, skill development, self-management, motivation, and self-assessment can strengthen the effect of digital literacy on the quality of learning. This is because the understanding of digital literacy that has every student who has been in a very high category is supported by the skill and experience in his educational environment will lead to higher education quality.

Based on the variable frequency distribution results, Self-Directed Learning (SDL) has an average value of 41.73 and is in a very high category. Digital literacy variables have an average value of 54.87 and are in very high categories. Learning quality variables have an average value of 45.75 and are in the high category. It means that students active in the accounting Education Department of Universitas Negeri Semarang, the year 2017, have perceived that he has Self-Directed Learning (SDL). This means that the student is active, independent, and able to plan goals until it evaluates everything needed in learning because of the environment's experience. The awareness and independence of students in improving the skills to improve digital literacy can improve learning quality. According to Bawden [19], There are eight essential elements in developing literacy skills: cultural, cognitive, constructive, communicative, and confident, responsible, creative, critical, socially responsible. The eight elements can be improved if each student has the ability to SelfDirected Learning (SDL) or can be said to be self-learning in resolving all of his responsibilities that are also assisted by educators. The presence of Self-Directed Learning (SDL) turned out to strengthen the positive influence of digital literacy. Very high student digital literacy, reinforced by a very great Self-Directed Learning (SDL) as well as a manifestation of student self-reliance on learning experience, can strengthen the positive influence of digital literacy on improved learning quality.

This study proved that the second hypothesis was accepted and showed results by the research Grant [14] presented the results of the research on the implementation of digital literacy at several schools to engage in selecting subject subjects, triggering the independence of learners in learning and improving the ability to communicate among students through the use of digital technology. It shows in a digital age like this, Self-Directed Learning (SDL) can not detach from digital literacy. This means that Self-Directed Learning (SDL) skills in the learning process can increase through excellent digital literacy capabilities. Through the use of unique technologies and digital devices, we are given the space to develop Self-Directed Learning (SDL) skills through various activities and resources such as participation in online learning groups, reflective writing activities, and online dialogue [15]. The results also showed that there was a positive correlation between digital literacy and quality Learning for learners studying in an online-based environment online [10]. Radovan [12] also shows the results that digital literacy has a positive influence on the quality of learning. Digital literation can contribute to more efficient task completion through software and computer programs, such as word processors or spreadsheets [13]. It can be concluded that the presence of very high digital literacy, supported by very high self-directed learning could increase the positive impact on the quality of learning. 


\section{Conclusion}

Based on the results of the analysis and discussion discovered in this research, it can conclude that digital literacy has no definite and significant effect on the learning quality. Selfdirected learning variables can moderate the positive influence of digital literacy on the quality of learning.

\section{References}

[1] "Declaration of Principles," World Summit on the Information Society, 2003. .

[2] S. Sukaesih and A. S. Rohman, "Literasi Informasi Pustakawan: Studi Kasus Di Universitas Padjadjaran,” J. Kaji. Inf. dan Perpust., vol. 1, no. 1, pp. 61-72, 2013.

[3] M. . Miftah, E. Rizal, and R. . Anwar, "Pola Literasi Visual Infografer Dalam Pembuatan Informasi Grafis (Infografis)," J. Kaji. Inf. dan Perpust., vol. 4, no. 1, pp. 87-94, 2016.

[4] K. Sholihah, "Analisis Literasi Digital: Studi Pemanfaatan Jurnal Elektronik oleh Mahasiswa Magister Manajemen di Perpustakaan UKSW Salatiga," UIN Sunan Kalijaga Yogyakarta., 2016.

[5] M. F. Akbar and F. D. Anggaraeni, "Teknologi Dalam Pendidikan: Literasi Digital Dan SelfDirected Learning Pada Mahasiswa Skripsi,” J. Indig., vol. 2, no. 1, pp. 28-38, 2017.

[6] K. Umam and I. Zaini, "Penerapan Media Digital Dalam Pembelajaran Apresiasi Batik Kelas X SMA Negeri 1 Blega," J. Pendidik. Seni Rupa, vol. 1, no. 1, pp. 100-105, 2013.

[7] I. Kurnianingsih, R. Rosini, and N. Ismayati, "Upaya Peningkatan Kemampuan Literasi Digital Bagi Tenaga Perpustakaan Sekolah dan Guru di Wilayah Jakarta Pusat Melalui Pelatihan Literasi Informasi," J. Pengabdi. Kpd. Masy., vol. 3, no. 1, pp. 61-76, 2017.

[8] H. Jossberger, S. Brand-Gruwel, H. Boshuizen, and M. Wiel, "The challenge of self-directed and self-regulat Sed learning in vocational education: a theoretical analysis and synthesis of requirements," J. Vocat. Educ. Train., vol. 62, no. 4, pp. 415-440, 2010.

[9] M. Gibbons, The self-directed learning handbook: Challenging adolescent students to excel. San Francisco: CA: Jossey-Bass., 2002.

[10] N. Hyland and J. Kranzow, "Faculty And Student Views Of Using Digital Tools To Enhance Self-Directed Learning And Critical Thinking," Int. J. Self-Directed Learn., vol. 8, no. 2, 2011.

[11] Ushfuriyah, "Hubungan Antara Dukungan Sosial Dengan Optimisme Mahasiswa Fakultas Psikologi UIN Maulana Malik Ibrahim Malang Dalam Menyelesaikan Skripsi,” J. Fak. Psikol. UIN Maulana Malik Ibrahim Malang, vol. 12, no. 1, 2015.

[12] V. Radovan, Digital Literacy as a Prerequisite for Achieving Good Academic Performance. Croatia: Ecil, 2014.

[13] G. Argentin, M. Gui, L. Pagani, and L. Stanca, "The Impact of Digital Literacy on Educational Outcomes : Evidence from Performance Tests,” Comput. Educ., no. August, pp. 1-19, 2014.

[14] L. Grant, Connecting digital literacy between home and school. Bristol: FutureLab, 2010.

[15] K. Saks and Ä. Leijen, "Distinguishing Self-Directed and Self-Regulated Learning and Measuring them in the E-learning Context," Procedia - Soc. Behav. Sci., vol. 112, no. Iceepsy 2013, pp. 190-198, 2014.

[16] Q. Suleman, "Factors responsible for unsatisfactory academic performance of the secondary school students in the rural areas of Kohat Division.," Am. J. Sci. Res., vol. 50, no. 43, pp. 4657, 2012.

[17] S. Stefany, Nurbani, and Badarrudin, "Literasi Digital Dan Pembukaan Diri : Studi Korelasi Penggunaan Media Sosial Pada Pelajar Remaja di Kota Medan," J. Pemikir. dan Penelit. Sosiol., vol. 2, no. 1, pp. 10-31, 2017.

[18] H. Yanto, J. M. Mula, and M. H. Kavanagh, "Developing student's accounting competencies using Astin's I-E-O model: An identification of key educational inputs based on Indonesian student perspectives," RMIT Account. Educ. Conf., pp. 1-24, 2011.

[19] Suryanti and L. Wijayanti, "Literasi Digital : Kompetensi Mendesak Di Era Revolusi Industri 
4.0,” J. Pendidik. Dasar, vol. II, no. 1, pp. 1-9, 2018.

[20] M. Coffin Murray and J. Perez, "Unraveling the digital literacy paradox: How higher education fails at the fourth literacy. Part of the Databases and Information Systems Commons Unraveling the Digital Literacy Paradox: How Higher Education Fails at the Fourth Literacy," Issues Informing Sci. Inf. Technol., vol. 11, pp. 85-100, 2014.

[21] S. Masitoh, "Blended Learning Berwawasan Literasi Digital Suatu Upaya Meningkatkan Kualitas Pembelajaran dan Membangun Generasi Emas 2045," Proc. ICECRS, vol. 1, no. 3, pp. 13-34, 2018. 